\title{
STUDI EKSPERIMENTAL PERFORMANCE KAVITASI WATERJET PROPULSI
}

\author{
W. M. Rumaherang ${ }^{1, *}$, J. Louhenapessy ${ }^{2}$, M. F. Noya ${ }^{3}$, C. S. Tupamahu ${ }^{4}$ \\ 1Jurusan Teknik Mesin Fakultas Teknik Universitas Pattimura, Ambon, 97233 \\ *Email: maxrumaherang72@gmail.com \\ 2Jurusan Teknik Mesin Fakultas Teknik Universitas Pattimura, Ambon, 97233 \\ Email: jandrileonora@yahoo.co.id \\ 3Jurusan Teknik Sistem Perkapalan Fakultas Teknik Universitas Pattimura, Ambon, 97233 \\ Email: mesakfrits@gmail.com \\ 4Jurusan Teknik Mesin Fakultas Teknik Universitas Pattimura, Ambon, 97233 \\ Email: tupamahucendy@gmail.com
}

\begin{abstract}
Abstrak. Kavitasi merupakan phenomena dari proses dinamis dalam mesin-mesin hidrolis yang dapat menyebabkan penurunan performance energy, menimbulkan getaran dan merusak permukaan blade. Analisa gejala kavitasi pada mesin-mesin hidrolis dilakukan melalui studi perfomance kavitasi, yaitu hubungan antara parameter-parameter energi. Setiap mesin mempunyai nilai kritis pada kurva performance kavitasi yang berbeda, karena itu studi pengaruh perubahan kavitasi dilakukan untuk menentukan zona kerja mesin tanpa kavitasi. Dalam penelitian ini analisa performance kavitasi dilakukan pada waterjet propulsor model dengan 5 blade impeller dan 7 blade stator dengan menggunakan metode eksperimen. Koefesien kavitasi divariasikan $\sigma=2,25$ sampai 0,25 melalui pengaturan dan pengontrolan tekanan inlet pada rig pengujian kavitasi. Titik kristis akan diobservasi pada pada titik dimana terjadi penurunan koefesien thrust sebesar $3,28 \%$. Hasil yang diperoleh menunjukan bahwa kavitasi mulai terjadi pada $\sigma=1$, titik kritis dipeoleh pada $\sigma=0,75$. Waterjet ini harus dioperasikan pada kondisi dimana $\sigma>$ 0,75 .
\end{abstract}

Kata kunci: waterjet propulsor, koefesien kavitasi, performance kavitasi

\begin{abstract}
Cavitation is a complex phenomenon of dynamic processes in hydraulic machines that can cause a decrease in energy performance, vibration and damage the blade surfaces. Analysis of cavitation symptoms in hydraulic machines is carried out through cavitation performance studies, namely the relations between energy parameters. Each hydraulic machine has a critical value on a different cavitation performance curve. Therefore, a study of the effect of cavitation changes is needed to determine the working zone of hydraulic machines without cavitation. In this study, cavitation performance analysis was carried out on a waterjet propulsor model with 5 impeller blades and 7 stator blades using experimental methods. The cavitation coefficient was varied at $\sigma=2.25$ to 0.25 by setting and controlling the inlet pressure on the cavitation test rig. The critical point value will be observed at the point where the thrust coefficient was decrease to $3.28 \%$. The results showed that cavitation begins at $\sigma$ $=1$, the critical point is obtained at $\sigma=0.75$. From this studies we find that waterjet must be operated at conditions where is $\sigma>0.75$.
\end{abstract}

Keywords: Waterjet propulsor, cavitation coefficient, cavitation performance

\section{PENDAHULUAN}

Kavitasi adalah phenomena dan proses dinamis yang kompleks yang ditandai dengan pecahnya kontinuitas cairan secara lokal dengan pembentukan dan penutupan rongga uap-gas. Ini adalah proses tidak stabil yang menyebabkan terjadinya pulsasi tekanan dan getaran, yang dapat merusakan permukaan blade impeller dan membahayakan konstruksi mesin-mesin hidrolik [1], [2]. Menurut Zhang dan Zhang [3] dan Tiweri 2020 [4] kavitasi bersifat multiphase tiga dimensi, discontinuous dan merupakan phenomena unsteady. Dengan berkembangnya 
kavitasi dala aliran maka terjadi penurunan tajam efisiensi dalam kurva performane kavitasi dan tahanan kekuatan material, memperpendek masa periodik reparasi dan maintenance, menambah intensitas tenaga kerja dan biaya operasional turbin [1] dan propeller [5].

Kavitasi dapat terjadi ketika tekanan lokal dari fluida cair lebih rendah dari tekanan uap jenuhnya [2] atau pada zona tekanan rendah yang ditunjukkan oleh distribusi volume fraksi uap menyeluruh dan kurva distribusi tekanan yang konstan sepanjang permukaan [6]. Diketahui bahwa ketika tekanan turun ke nilai tekanan uap $\mathrm{P}_{\mathrm{d}}$ dalam fluida kontinu, cairan mulai mendidih dan sejumlah besar gelembung gas uap kecil yang bersifat ledakan muncul dan meningkat dengan cepat. Jika zona ekspansi cukup panjang, rongga kavitasi terbentuk dari gelembung. Pada saat itu terjadi perubahan fase tunggal menjadi aliran dua fase dan prinsip kontinutas aliran tidak berlaku [1].

Fenomena kavitasi aliran pada mesin-mesin hidrolik sangat ditentukan oleh proses design, pengoperasian serta perbaikan mesin seperti pompa, turbin [7] dan juga blade pompa propulsor dalam berbagai tingkatan [6]. Bentuk blade dan pitsnya dapat menyebebkan terbentuknya kavitasi secara bertahap dan secara ekstrim dapat merusak material blade [8]. Selain pada impeller dan stator, kavitasi juga dapat terjadi pada duct saluran masuk yang dapat menyebabkan erosi dan vibrasi sehingga harus dihilangkan.

Penelitian karakteristik kavitasi dilakukan untuk meninjau kavitasi pada impeller, stator dan juga pada saluran masuk. Hasil-hasil penelitian melalui eksperimen atau simulasi hidrodinamika menunjukan bahwa pada penurunan koefisien kavitasi $\sigma$ [9] atau NPSH [2] terjadi penurunan head dan efisiensi yang tajam, akibat penurunan tekanan pada profil impeller [4]. Demikian juga pada variasi nilai Q/Qmax yang kecil nilai efesiensi akan turun secara tajam sesuai hasil studi yang dilakukan oleh Sinagra et al [10] yang dikutip oleh G. Tiweri et al [4].

Kavitasi pada saluran masuk dilakukan melalui analisis distribusi tekanan air di sekitar penampang inlet. Oleh karena itu, kemungkinan kavitasi diselidiki dan dikendalikan dengan cermat melalui pengaturan angka atau koefisien kavitasi [11]. Penelitian kavitasi pada profil NACA 0012 dilakukan melalui variasi koefisien kavitasi K [1] sedangkan pada turbin dilakukan dengan memvariasikan koefisien kavitasi $\sigma$, melalui pengaturan tekanan outlet, sesuai dengan kondisi sisi keluar turbin [9] dan pada pompa waterjet dilakukan dengan variasi koefisien kavitasi $\sigma \quad[4][7][9][12][13]$ yang dikontrol melalui pengaturan tekanan inlet.

Waterjet propulsi merupakan suatu sistem yang kompleks, yang belakangan ini dikembangkan dan digunakan diaplikasikan pada kapal-kapal cepat dengan kemampuan manuver yang lebih tinggi, membuat penggunaan waterjet lebih menarik karena talah dihasilkan pompapompa dengan kecepatan tinggi dan efesiensi yang tinggi [11].. Pompa axial [14] digunakan dalam berbagai aplikasi teknik termasuk pada pompa pemanas, pompa propane pada system pembakaran roket dan paling banyak digunakan sebagai waterjet propulsor pada kapal cepat, namun permasalahan penting yang sampai saat masih tetap diteliti adalah masalah pengaruh kavitasi. Hal ini karena kecepatannya yang tinggi sehingga sangat rawan terhadap bahaya kavitasi.

Para peneliti telah membuat kemajuan besar dalam studi kavitasi, tetapi masalah kavitasi dalam kondisi khusus dalam sistem propulsi waterjet masih merupakan faktor penting analisa kinerja hidroliknya [6].

Kavitasi aliran mempengaruhi karakter aliran dalam penampang waterjet. Perubahan tingkat kavitasi yang ditandai dengan koefisien kavitasi $\sigma$ atau NPSH [6],[15][16] merubah profil distribusi tekanan dan kecepatan aliran dan selanjutnya menyebabkan perubahan performance waterjet, selain dari pengaruh bentuk dan geometri waterjet yang masih perlu ditinjau secara luas, dan karena itu dalam paper ini dianalisa pengaruh nilai koefesien kavitasi terhadap profil aliran dan performance kavitasi pompa waterjet propulsor dan menentukan titik koefesien kritis kavitasi, yaitu nilai koefisien dimana performance waterjet turun sampai dengan 3,28\% [6]. Performance kavitasi mencakup berbagai parameter. Namun dalam penelitian hanya dianalisa parameter tekanan, kecepatan, koefesien thrust $\mathrm{K}_{\mathrm{t}}$ dan koefisien head $\mathrm{K}_{\mathrm{H}}$.

Metode yang saat ini paling efektif adalah experimental dan simulasi numerik [1][2][4][6] [9]. Dalam paper ini karakteristik kavitasi dianalisa melalui metode eksperimen untuk model waterjet [17] dengan 5 blade impeller dengan bentuk dan ukuran yang sudah dimodifikasi.

\section{BAHAN DAN METODE}

\subsection{Parameter-parameter Energi Turbo Mesin}

Waterjet propulsion sistem memiliki tiga komponen utama: inlet, pump and nozzle [11][14]. Water jet propulsor termasuk dalam pompa aksial yang terdiri dari sudu-sudu impeller dan sudu-sudu pengarah [14]. Profil aliran dalam 
setiap penampang secara teoritis dihitung dengan pendekatan aliran turbulen yang diekspresikan ulang oleh Creswell et al [18] dan Steven Alshop et al [19], yaitu :

$$
\frac{v}{U_{o}}=\left(\frac{r}{R}\right)^{1 / 7}
$$

Berdasarkan persamaan torsiturm thrust yang efesien adalah relasi pada perubahan torsitum aliran fluida dalam nosel [20][21] yang dinyatakan sebagai:

$$
T=\rho Q\left(V_{j}-c v_{m}\right)=\rho Q V_{m}(a-1)
$$

Dimana $\rho$ adalah densitas fluida $[\mathrm{kg} / \mathrm{m} 3], \quad Q$ adalah debit aliran $\left[\mathrm{m}^{3} / \mathrm{s}\right], \mathrm{Vj}$ adalah kecepatan keluar jet dari nosel $[\mathrm{m} / \mathrm{s}]$, Vm adalah kecepatan aliran masuk ke impeller $[\mathrm{m} / \mathrm{s}]$, dan $a=\frac{V_{j}}{V_{i}}=$ $\left(D / D_{j}\right)^{2}$ adalah rasio jet [20].

$$
V_{j}=\frac{4 Q}{\left(\pi D_{j}^{2}\right)} \text { dan } V_{m}=\frac{4 Q}{\left(\pi D^{2}\right)}
$$

Head pompa dipengaruhi oleh kondisi aliran di inlet, nozzle, dan posisi kedalaman jet dan dinyatakan sebagai berikut [22]:

$$
H_{p}=\frac{1}{2 g}\left[V_{j}^{2} \eta_{n}-V_{i}^{2} \eta_{i}+2 g h_{j}\right]
$$

Dengan memperhitungkan kerugian-kerugian kecil lainnya, maka head dan debit sistem waterjet ditentukan juga dengan memperhitungkan nilai koefisien thrust $\mathrm{K}_{\mathrm{t}}$ dan torsi $\mathrm{K}_{\mathrm{Q}}$ [12]. Nilai kedua koefisien ini secara berturut dinyatakan dengan persamaan :

$$
\begin{aligned}
& K_{T}=\frac{T}{\rho n^{2} D^{4}} \\
& K_{Q}=\frac{M_{z}}{\rho n^{2} D^{5}}
\end{aligned}
$$

Menurut Golikov dan W.M. Rumaherang, 2011 [14], kemampuan anti-kavitasi mesin-mesin hidrolik ditentukan oleh koefisien kecepatan spesifik kavitasi dinyatakan sebagai:

$$
C_{k r}=\frac{5.62 n \sqrt{Q}}{\Delta h_{\text {sup }}^{3 / 4}}
$$

Dimana : $\mathrm{n}=$ putaran poros $1 / \mathrm{min} ; \mathrm{Q}=$ debit, $\mathrm{m}^{3} / \mathrm{s}, \Delta$ hsup $=$ keamanan kavitasi tersedia, yang sama dengan koefisien kavitasi. Pada pompa dengan kondisi-kondisi khusus dibawah syarat kavitasi, nilai koefisien kecepatan specific berada pada range $\mathrm{C}_{\mathrm{kr}}=900 \div 1000$

Mirip dengan desain turbin yang dilakukan oleh W. M. Rumaherang et al [23], diameter impeller ditentukan berdasarkan kecepatan aliran fluida pada penampang meridian $\left(\mathrm{V}_{\mathrm{m}}\right)$ dan debit
(Q). Dari perhitungan konstruksi dan kekuatan poros, maka kecepatan pada daerah impeller adalah [23][24][25]:

$$
V_{m}=\frac{4 Q}{\pi D_{1}^{2}\left(1-d_{b s}^{2}\right)}
$$

Koefesien tekanan dinyatakan sebagai berikut [12]:

$$
C_{p}=\frac{p-p_{\infty}}{\frac{1}{2} \rho(n D)^{2}}
$$

Seperti yang telah disebutkan bahwa syarat permulaan kavitasi pada titik mana pun adalah terjadinya penurunan tekanan pada titik ini ke tekanan uap air jenuh pada sudu impeller. Perbedaan antara tekanan pada setiap titik sudu dan tekanan penguapan $p_{\mathrm{v}}$ ditentukan oleh rumus [9]:

$$
\frac{p_{\infty}-p}{\rho g H}=\sigma_{s}-\sigma_{w j}
$$

Dengan mensubtitusi koefesien tekanan dalam penelitian Takayuki Watanabe et al [12], ke persamaan koefisien kavitasi yang ditulis dalam penelitian yang dilakukan oleh W.M. Rumaherang dan Topazh G.I [9] maka koefisien kavitasi ditulis menjadi:

$$
\sigma=\frac{p_{\infty}-p_{v}}{\frac{1}{2} \rho(n D)^{2}}=\frac{N P S E}{E}=\frac{p_{\infty}-p}{\rho g H}=-C_{p}
$$

Hasil dari persamaan (11) dibandingkan dengan syarat persamaan (7), menunjukkan kondisi anti-kavitasi pompa propulsor tersebut.

\subsection{Bentuk dan Ukuran Model Waterjet Propulsor}

Waterjet propulsor didesain dengan prosedur desain pompa aksial pada persamaan (8), [9] menghasilkan bentuk dan geometri yang diadaptasikan sesuai syarat-syarat untuk waterjet propulsor. Ukuran-ukuran pompa yang didesain dan diuji ditampilkan dalam Tabel 1.

Tabel 1. Ukuran-ukuran utama impeller dan stator

\begin{tabular}{cccc}
$\begin{array}{c}\text { Impeller/Stator } \\
\text { model }\end{array}$ & Simbol & Impeller & Stator \\
\hline Dia. max $(\mathrm{mm})$ & $\mathrm{D}_{1}$ & 120 & 120 \\
$\begin{array}{c}\text { Dia. min }(\mathrm{mm}) \\
\text { Rasio dia. }\end{array}$ & $\mathrm{D}_{2}$ & 100 & 76 \\
$\mathrm{~d}^{\mathrm{D}} \mathrm{D}_{2}$ & 0,63 & 0.63 \\
Jumlah blade & $\mathrm{z}$ & 5 & 7 \\
$\quad \begin{array}{c}\text { Material } \\
\text { Luas }\end{array}$ & - & bronze & bronze \\
$\begin{array}{c}\text { Permukaan Inlet } \\
\left(\mathrm{m}^{2}\right)\end{array}$ & $\mathrm{A}_{\text {in }}$ & 0.00785 & 0.11304 \\
\hline
\end{tabular}




\subsection{Peralatan Test dan Metode}

Instalasi pengujian pompa axial sebagai water jet dilakukan untuk mengukur pengaruh koefesien kavitasi terhadap parameter-parameter energi yaitu head [6][7][9] [26] dan terhadap thrust [11].

Instalasi pengujian yang dirancang diadopsi model riset yang dilakukan oleh Jie Dang [17][26][16] dengan menambahkan sebuah pompa yang mengontrol kecepatan aliran horizontal pada inlet duct.

Pengukuran performance kavitasi dilakukan melalui variasi nilai koefisien kavitasi $\sigma$ pada persamaan (10) dan (11), yang kontrol melalui pengaturan tekanan pada tanki 1 yang diindikasikan oleh pressure gauge 1. Nilai pressure gauge diperoleh melalui pengaturan kerja kompresor 4 dan 5.

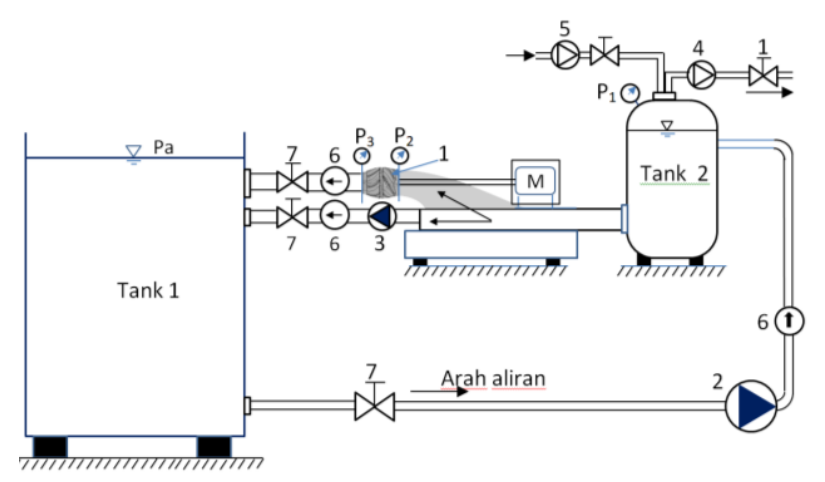

Gambar 1. Diagram skematis dari rig eksperimen:

1. Waterjet propulsor, 2. Pompa input,

3. Pompa kontrol, 4 \& 5 Kompressor,

6. magnetic flowmeter, 7. Katup

kontrol, $\mathrm{P}_{1}, \mathrm{P}_{2}, \mathrm{P}_{3}=$ pressure gauge.

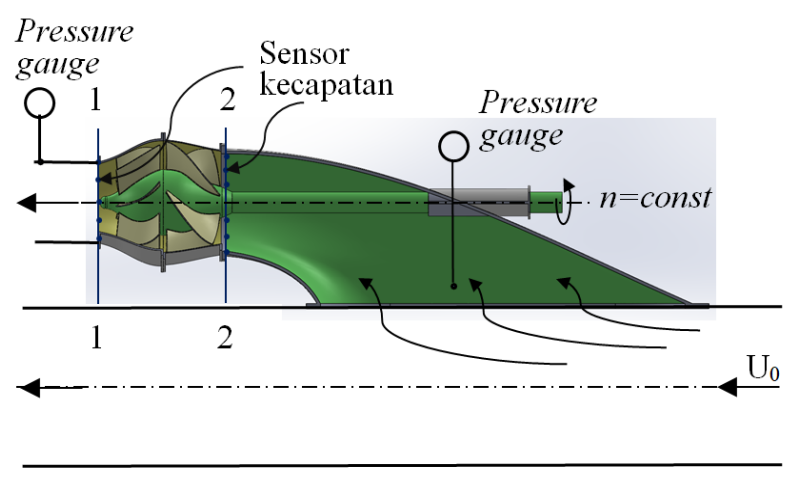

Gambar 2. Testing pompa axial

Pengukuran perfomance kavitasi dilakukan melalui variasi nilai koefesien kavitasi $\sigma$ pada persamaan (10) dan (11), yang kontrol melalui pengaturan tekanan pada tanki 1 yang diindikasikan oleh pressure gauge 1. Nilai pressure gauge diperoleh melalui pengaturan kerja kompresor 4 dan 5. Pengukuran dilakukan pada putaran poros waterjet konstan $\mathrm{n}=2400$ $1 /$ min dan debit $\mathrm{Q}=0.038 \mathrm{~m}^{3} / \mathrm{s}$. Kecepatan aliran inlet dalam arah sumbu $\mathrm{x}$, yaitu $\mathrm{u} 0=$ konstan, yang dikontrol dengan kerja pompa 1 dan 3.

Pengukuran perfomance kavitasi dilakukan melalui variasi nilai koefisien kavitasi $\sigma$ pada persamaan (10) dan (11), yang kontrol melalui pengaturan tekanan pada tanki 1 yang diindikasikan oleh pressure gauge 1. Nilai pressure gauge diperoleh melalui pengaturan kerja kompresor 4 dan 5. Pengukuran dilakukan pada putaran poros waterjet konstan $n=2400$ $1 / \mathrm{min}$ dan debit $\mathrm{Q}=0.038 \mathrm{~m}^{3} / \mathrm{s}$. Kecepatan aliran inlet dalam arah sumbu $\mathrm{x}$, yaitu $\mathrm{u}_{0}=$ konstan, yang dikontrol dengan kerja pompa 1 dan 3.

Data hasil pengukuran yang ditunjukkan oleh sensor kecepatan digunakan untuk menggambar profil kecepatan pada sensor yang terpasang sepanjang spanwise pada penampang inlet duct dan pada titik koneksi inlet duct dan impeller (penampang 1-1) dan dan oulet stator (penampang 2-2). Nilai nilai head dan thrust waterjet diperoleh dengan formula (2) dan (3), berdasarkan hasil pengukuran tekanan dan kecepatan pada semua penampang.

\subsection{Karakteristik Kavitasi Waterjet}

Karakteristik pompa waterjet propulsi menggambarkan karakteristik kavitasi yaitu pengaruh koefesien kavitasi terhadap head $\mathrm{H}_{\mathrm{p}}$, thrust $\mathrm{T}_{\mathrm{j}}$ dan torque $\mathrm{M}_{\mathrm{Z}}$. Dalam panelitian ini hubungan ini dinyatakan melalui pengaruh kavitasi terhadap koefesien head $\mathrm{K}_{\mathrm{H}}$, koefesien thrust $\mathrm{K}_{\mathrm{t}}$ yaitu $K_{H}, K_{t}=f(\sigma)$. Setelah digambarkan karaketeriktik kavitasi, maka ditemukan titik kritis kavitasi, yaitu titik dimana koefesien head $\mathrm{K}_{\mathrm{H}}$ dan koefesien thrust $\left(\mathrm{K}_{\mathrm{Q}}\right)$ pada kurva performance pompa turun, 3,28\% dibawah nilai-nilainya yang diperoleh pada kondisi aliran tanpa kavitasi.

\section{HASIL DAN PEMBAHASAN}

\subsection{Flow Velocity And Pressure Profiles Pada Penampang Saluran Masuk}

Pada pengampang aliran masuk diukur tekanan dan kecepatan pada sensor yang dipasang sepanjang garis tengah penampang melintang 1-1 yang menghubungkan koordinat titik $(0,-0,09$, $0,015)$ dengan koordinat $(0,-0,015,-0,33)$. Pada jarak antara sensor-sensor tersebut, nilai tekanan dan kecepatan diperoleh melalui interpolasi. Nilai tekanan pada penumpang dipengaruh oleh nilai koefesien kavitasi $\sigma$, yang divariasikan melalui variasi nilai tekanan pada tangki 2. Nilai tekanan dan kecepatan pada variasi nilai koefesien kavitasi 
$\sigma=2.25,0.98$ dan 0,52 ditampilkan pada gambar 3 dan Gambar 4.

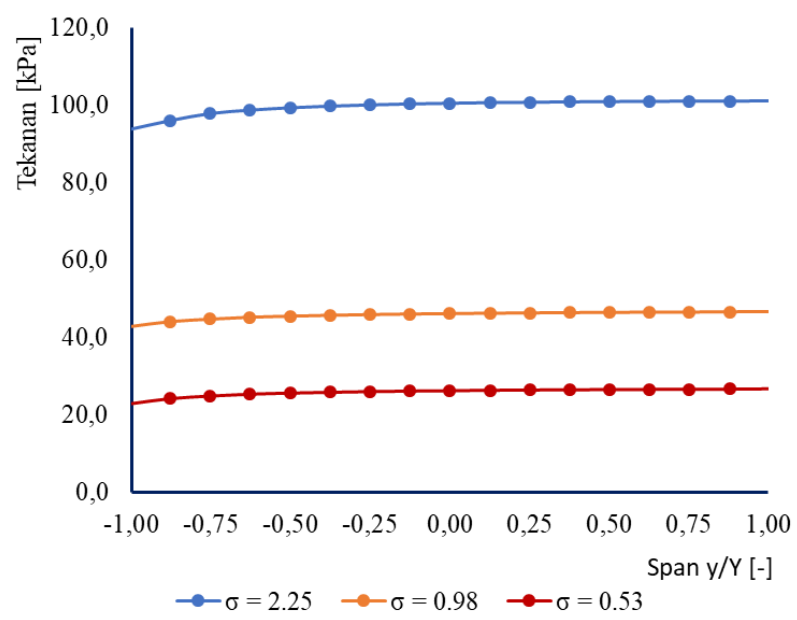

Gambar 3. Distribusi tekanan fluida pada penampang saluran masuk (inlet passage)

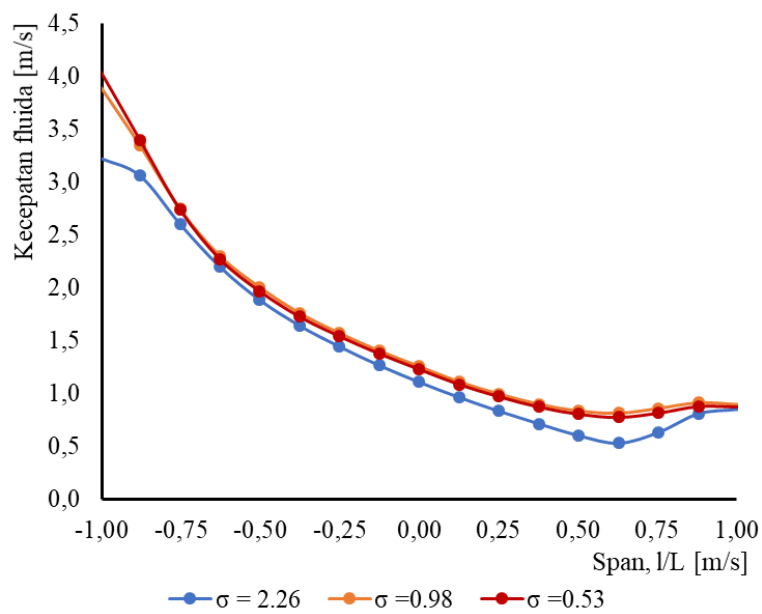

Gambar 4 Distribusi kecepatan aliran fluida pada penampang saluran masuk (inlet passage)

Pada gambar 3 nilai tekanan bervariasi sepangang garis tengan penampang, dimana tekanan minimum ditemukan pada span $(l / L)=$ 1,0 dan meningkat sampai mencapai nilai maksimum ditemukan pada span $(l / L)=1,0$. Dengan variasi nilai koeffesien kavitasi, nilai distribusi tekanan sepanjang span mengalami perubahan, dimana distribusi tekanan turun bersamaan dengan turunnya nila koefesien kavitasi. Nilai koefesien kavitasi $\sigma=2.25$ adalah nilai dimana tidak ditemukan fenomena kavitasi (non cavitational flow). Dengan menurunkan tekanan pada tanki 2, distrubusi tekanan pada saluran inlet pompa waterjet propulsor mengalami penurunan beraturan dengan bentuk profil tekanan serupa.

Pada gambar 4. nilai kecepatan bervariasi sepangang garis tengan penampang, dimana kecepatan maksimum ditemukan pada span $(I / D)$ $=-1,0$ dan berkurang sampai mencapai nilai minimum ditemukan pada span $(l / L)=1,0$. Pada nilai tekanan minimum, kecepatan mencapai maksimum dan sebaliknya. Sama dengan perubahan nilai distribusi tekanan, distribusi kecepatan sepanjang spanwise mengalami perubahan. Nilai kecepatan meningkat dengan turunnya nilai tekanan pada tanki 2. Namun pada nilai koefisien kavitasi yang kecil (cavitational flow), nilai kecepatan mengalami penurunan dibandingkan aliran tanpa kavitasi.

\subsection{Flow Velocity And Pressure Profiles Pada Penampang Koneksi Impeller Dan Inlet Passage}

Pada penampang aliran di depan impeller diukur tekanan dan kecepatan pada sensor yang dipasang sepanjang garis tengah penampang melintang 2-2. Sama dengan inlet passage pada jarak antara sensor-sensor tersebut, nilai tekanan dan kecepatan diperoleh melalui interpolasi untuk mendapatkan nilai-nilai tekanan dan kecepatan. Nilai tekanan pada penumpang dipengaruhi oleh nilai koefisien kavitasi $\sigma$. Nilai tekanan dan kecepatan pada variasi nilai koefesien kavitasi $\sigma=$ $2.25,0.98$ dan 0,52 pada penampang 2-2 ditampilkan pada gambar 5 dan Gambar 6 .

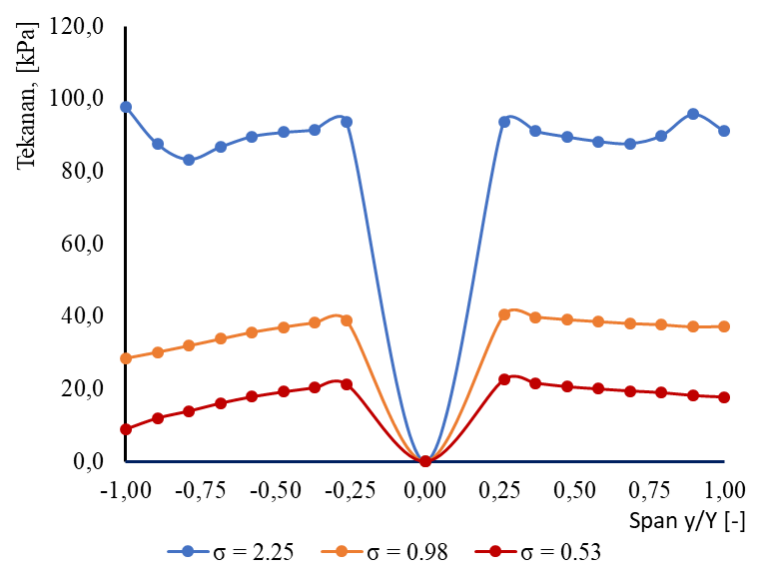

Gambar 5. Distribusi tekanan fluida pada penampang koneksi impeller dan inlet passage 


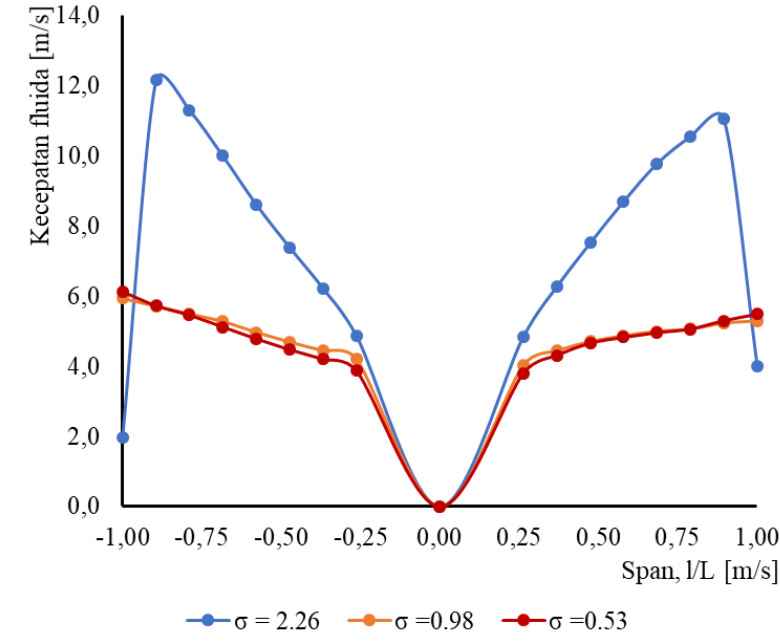

Gambar 6. Distribusi kecepatan aliran fluida pada penampang koneksi impeller dan inlet passage

Pada Gambar 5, nilai tekanan statis bervariasi sepangang garis tengah penampang, dimana tekanan minimum ditemukan pada span $(r / D)=$ 0.789 dan maksimum ditemukan pada span $(r / D)$ 1,0 untuk aliran tanpa kavitasi (non cavitational flow). Selanjutnya tekanan mencapai maksimum di titih hub impeller atau pada titik jari-jari poros pompa. Nilai tekanan nol menunjukan daerah poros yang tidak dilalui aliran. Dengan variasi nilai koefisien kavitasi $\sigma$, nilai distribusi tekanan sepanjang span $(r / D)$ mengalami penurunan proporsional dengan perubahan tekanan pada tangka 2, dimana distribusi tekanan turun bersamaan dengan turunnya nila koefesien kavitasi.

Pada Gambar 6, nilai kecepatan bervariasi sepangang garis tengan penampang, dimana kecepatan maksimum pada daerah pheripheri yaitu pada span $(r / D)=-1,0$ dan span $(r / D)=1,0$ dan minimum pada daerah hub/poros yaitu pada span $\operatorname{span}(r / D)=-0.26$ dan $\operatorname{span}(r / D)=0.26$. Pada nilai tekanan minimum, kecepatan mencapai maksimum dan sebaliknya. Sama dengan perubahan nilai distribusi tekanan, distribusi kecepatan sepanjang spanwise mengalami perubahan. Nilai kecepatan meningkat dengan turunnya nilai tekanan pada tanki 2. Namun pada nilai koefisien kavitasi yang kecil (cavitational flow), nilai kecepatan mengalami penurunan dibandingkan aliran tanpa kavitasi.

Pada penampang koneksi impeller dan inlet passage, terlihat pengaruh shroud dan hub terhadap profil aliran pada penampang, demikian juga bentuk saluran masuk membentuk opal aliran pada aliran sampai pada koneksi saluran masuk dengan impeller, sehingga kecepatan pada kedua sisi pheripheri tidak sama.

\subsection{Flow Velocity And Pressure Profiles Pada Penampang Koneksi Impeller dan Inlet Passage}

Pada penampang aliran di depan impeller diukur tekanan dan kecepatan pada sensor yang dipasang sepanjang garis tengah penampang melintang 3-3 di outlet nozel. Sama dengan inlet passage pada jarak antara sensor-sensor tersebut, nilai tekanan dan kecepatan diperoleh melalui interpolasi untuk mendapatkan nilai-nilai tekanan dan kecepatan. Nilai tekanan dan kecepatan pada variasi nilai koefesien kavitasi $\sigma=2.25,0.98$ dan 0,52 pada penampang 3-3 (outlet nozel) ditampilkan pada gambar 7. dan gambar 8 .

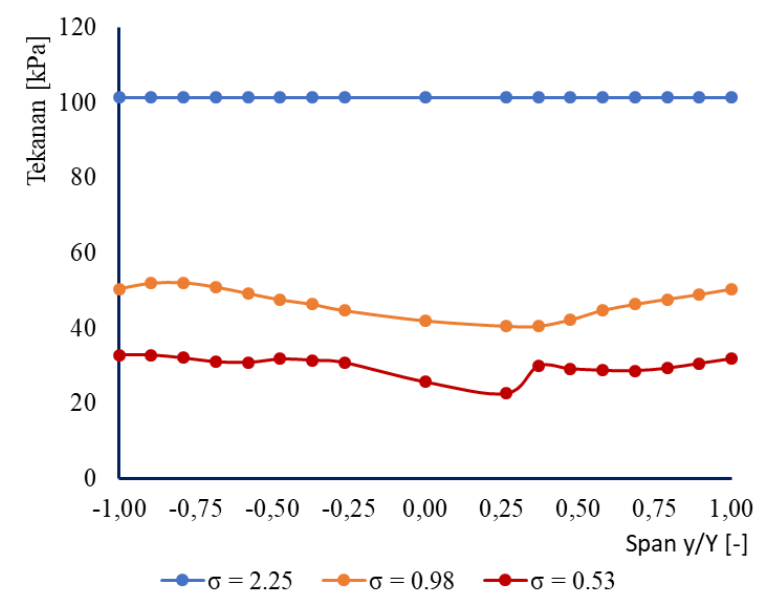

Gambar 7. Distribusi tekanan fluida pada penampang saluran masuk (inlet passage)

Pada Gambar 7, nilai tekanan statis bervariasi sepangang garis tengah penampang, dimana tekanan minimum ditemukan pada span $(\mathrm{r} / \mathrm{D})=$ 0.789 dan maksimum ditemukan pada span (r/D) 1,0 untuk aliran tanpa kavitasi (non cavitational flow). Pada aliran tanpa kavitasi, tekanan statis ditemukan mendekati nilai tekanan atmosfer dan terdistribusi merata spanjang spanwise ( $\mathrm{r} / \mathrm{D})$. Dengan munculnya kavitasi aliran, tekanan titik seragam sepanjang spanwise (r/D). Sama dengan saluran inlet dan aliran di depan impeller, tekanan turun proporsional dengan penurunan nilai koefisien kavitasi.

Serupa dengan kondisi aliran pada di depan impeller, pada Gambar 8 nilai kecepatan bervariasi sepanjang garis tengah penampang, dimana kecepatan maksimum pada daerah pada $\operatorname{span}(\mathrm{r} / \mathrm{D})=-0.8$ dan $\operatorname{span}(\mathrm{r} / \mathrm{D})=0.8$ dan dipengaruhi oleh bentuk pheripheri nosel. Perubahan profil aliran pada ujung nosel mengindikasikan terjadinya kavitasi pada impeller dan stator. 
Profil kecepatan aliran yang melalui secara umum menunjukan kesesuaian dengan pola aliran yang dibentuk dengan pendekatan aliran turbulen. Dimana distribusi kecepatan pada setiap jarak radius $r$ dari penempang saluran yang ditunjukan melalui pesamaan pangkat 1/7 [18][19].

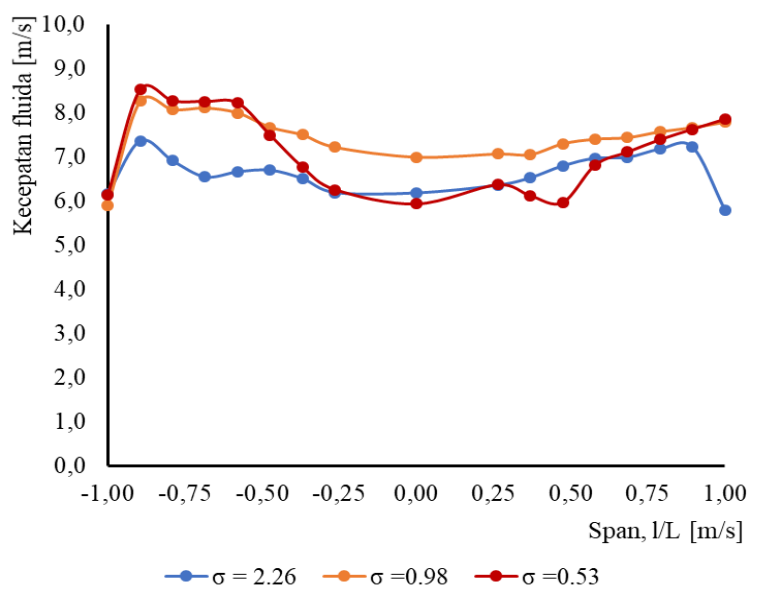

Gambar 8. Distribusi kecepatan aliran fluida pada penampang saluran masuk (inlet passage)

Profil aliran pada penampang nosel tidak menunjukkan kondisi yang sama dengan distribusi kecepatan aksial yang dihasilkan dalam penelitian Chuang Wang [26]. Oleh karena itu masih perlu ditinjau demikian masih dibutuhkan penelitian lanjutan tentang pengaruh bentuk dan ukuran stator dan nosel.

\subsection{Pengaruh Kavitasi Terhadap Kecepatan Jet.}

Pengaruh kavitasi kecepatan ditunjukan melalui Gambar 9, hubungan kecepatan jet fluida $\mathrm{Vj}$ pada nosel dan kecepatan fluida pada penampang meridian di depan impeller $\mathrm{Vm}$. Kedua nilai kecepatan ini, tidak mengalami perubahan pada angka koefesien kavitasi $\sigma>1$ atau pada titik design. Hal ini menunjukan bahwa pada kondisi aliran tanpa kavitasi tidak berpengaruh terhadap rata-rata kecepatan jet dan kecepatan meridian Vm.

Pada Gambar 9, gejala kavitasi ditemukan ketika nilai koefisien kavitasi $\sigma<1$. Munculnya fenomena kavitasi ditandai melalui penurunan kecepatan jet Vj dan Vm. Pada tahap awal terjadi kavitasi kecepatan jet sedikit mengalami peningkatan, selanjutnya kecepatan menurun secara drastis dengan penurunan koefesien kaviatasi $\sigma$.

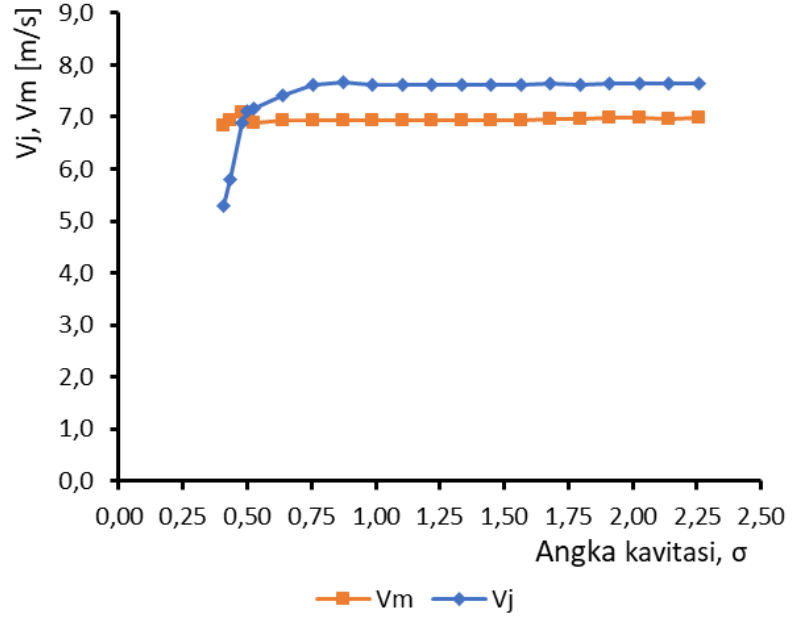

Gambar 9. Pengaruh kavitasi terhadap kecepatan aliran fluida didepan impeller

\subsection{Karakteristik Kavitasi}

Karaketristik kavitasi dilukiskan dalam kurva hubungan koefisien kavitasi terhadap parameter head, thrust dan torsi yang diukur pada poros impeller. Dalam penelitian ini dikaji hanya pengaruh kavitasi terhadap koefisien thrust $\mathrm{Kt}$ dan koefisien torsi $\mathrm{K}_{\mathrm{Q}}$. Pada Gambar 10, nilai Kt dan $\mathrm{K}_{\mathrm{Q}}$ mengalami penurunan ketika terjadi kavitasi pada aliran ini. fenomena ini terjadi ketika nilai koefesien kavitasi $\sigma<1$. Koefisien thrust $\mathrm{Kt}$ mengalami peninkatan pada $\sigma<1$ dan selanjutnya turun secara ekstrim dengan penurunan nilai koefisien $\sigma$. Koefisien torsi mengalami peningkatan pada $\sigma=0.5$ dan selanjutnya mengalami penurunan brutal untuk $\sigma<0.5$.

Titik kritis diperoleh dimana koefisien thrust mengalami penurunan sampai $3.25 \%$ dibawah koefesien thrust Kt titik rancang [6]. Kondisi ini terjadi pada nilai $\sigma=0.75$.

Nilai ini jika dibandingkan dengan hasil penelitian analisis dinamis kavitasi tip vortex pompa jet propeller yang dilakukan oleh Jianping Yuan [27] dimana titik kritis dengan penurunan Kt 3,25\% ditemukan pada nilai koefesien kavitasi pada nilai $\sigma=0.75-1$. Berbeda dengan hasil penelitian analisis numerik aliran dua phasa dalam proses kavitasi [6] dimana kondisi kritis diperoleh pada nilai NPSHa $=1,32$ yang setara dengan $\sigma=$ 0,4 . Pada penelitian kavitasi pada marine propeller yang dilakukan oleh Takayuki Watanabe et al [12], nilai koefesien kristis kavitasi ditemukan pada nilai $\sigma=1,0$ - 1,2. 


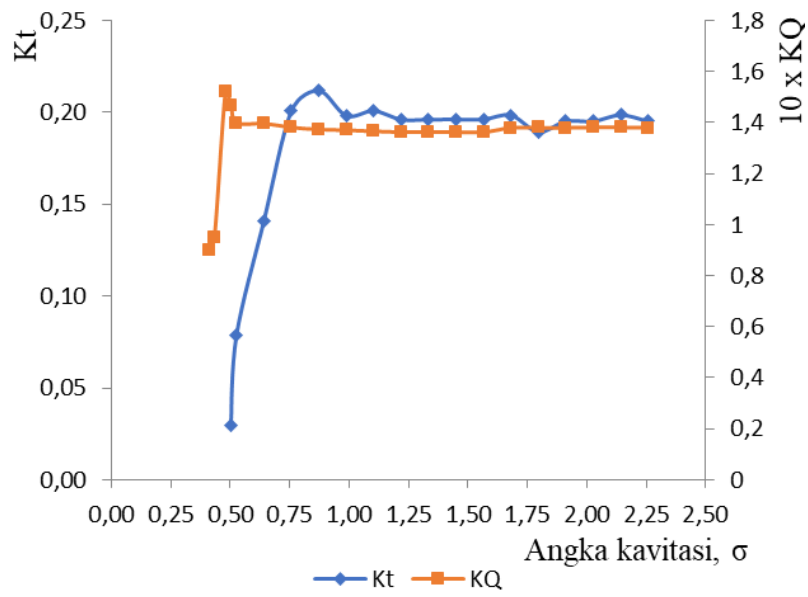

Gambar 10. Performance kavitasi waterjet propulsor 5 blade : Pengaruh koefesien kavitasi terhadap koefesien thrust dan torsi

Beberapa faktor memberikan pengaruh terhadap hasil ini, yaitu bentuk dan geometri sistem pompa waterjet khususnya pada impeller dan stator, serta kondisi-kondisi parameter aliran debit Q dan juga putaran poros.

Karena penelitian harus dilakukan untuk mengetahui pengaruh bentuk dan ukuran sistem impeller dan stator serta pengaruh debit dan putaran pada munculnya fenomena kavitasi pada waterjet.

\section{KESIMPULAN}

Berdasarkan hasil dan pembahasan, maka dibuat kesimpulan sebagai berikut:

Pada bagian saluran masuk, didepan impeller pada nosel, profil aliran berubah mengikuti bentuk dan ukuran penampang dan arah aliran. Penurunan tekanan pada sisi masuk menyebabkan penurunan tekanan dalam nosel. Sebelum terjadi kavitasi, penurunan nilai koeefesien kavitas tidak merubah parameter-parameter energi, yaitu kecepatan, koefisien thrust dan koefisien torsi. Kavitasi mulai terjadi pada nilai koefisien kavitasi $\sigma=1$, ditandai dengan naiknya kecepatan jet dan koefisien thrust $\mathrm{Kt}$ dan kemudian turun dengan pengecilan nilai koefisien kavitasi. Pada gejala kavitasi lanjut, kecepatan, koefesien thrust dan koefesien torsi turun secara ekstrim dengan kemiringan kurva yang sangat curam. Nilai koefisien kavitasi kritis pada kurva koefesien thrust diperoleh pada $\sigma_{\mathrm{cr}}=0.65$. Koefisien kavitasi kritis untuk penurunan nilai torsi ditemukan pada $\sigma_{\mathrm{cr}}=0,4$. Untuk kondisi kerja tanpa kavitasi, maka sistem pompa waterjet propulsor 5 blade dalam penelitian ini maka kondisi kerja harus menjamin nilai koefesien kavitasi harus lebih dari $1(\sigma \geq 1)$.

\section{DAFTAR PUSTAKA}

[1] W. M. Rumaherang, Topazh G.I. “Оценка эффективности моделирования кавитационного течения жидкости с помощью баротропной модели расчета (C) 2012," pp. 645-648, 2012, [Online]. Available: https://cyberleninka.ru/article/n/otsenkaeffektivnosti-modelirovaniyakavitatsionnogo-techeniya-zhidkosti-spomoschyu-barotropnoy-modeli-rascheta.

[2] S. Zhang, R. Zhang, S. Zhang, and J. Yang, "Effect of Impeller Inlet Geometry on Cavitation Performance of Centrifugal Pumps Based on Radial Basis Function," Int. J. Rotating Mach., vol. 2016, 2016, doi: 10.1155/2016/6048263.

[3] H. Zhang and L. Zhang, "Numerical simulation of cavitating turbulent flow in a high head Francis turbine at part load operation with OpenFOAM," Procedia Eng., vol. 31, pp. 156-165, 2012, doi: 10.1016/j.proeng.2012.01.1006.

[4] G. Tiwari, J. Kumar, V. Prasad, and V. K. Patel, "Utility of CFD in the design and performance analysis of hydraulic turbines - A review," Energy Reports, vol. 6, no. November, pp. 2410-2429, 2020, doi: 10.1016/j.egyr.2020.09.004.

[5] O. Usta, C. S. Koksal, and E. Korkut, "A Study on Cavitation Erosion Resistance of Marine Propeller Materials, Using a Water Jet Test Rig A Study on Cavitation Erosion Resistance of Marine Propeller Materials , Using a Water Jet Test Rig," no. November, 2018.

[6] W. Jiao, L. Cheng, J. Xu, and C. Wang, "Numerical analysis of two-phase flow in the cavitation process of aWaterjet propulsion pump system," Processes, vol. 7, no. 10, 2019, doi: 10.3390/pr7100690.

[7] F. Avellan, "Introduction to cavitation in hydraulic machinery," 6th Int. Conf. Hydraul. Mach. Hydrodyn., no. January 2004, pp. 11-22, 2004, [Online]. Available: http://mmut.mec.upt.ro/mh/Conferinta_MH /102Avellan.pdf.

[8] M. Volk, Pump Characteristics and Applications. 2013.

[9] W. M. Rumaherang, Topazh G.I "Расчет кавитационного обтекания рабочего колеса радиально - осевой гидротурбины (C) 2011," vol. 1, no. 2, pp. 472-475, 2011. 
[10] M. Sinagra, V. Sammartano, C. Aricò, A. Collura, and T. Tucciarelli, "Cross-Flow turbine design for variable operating conditions," Procedia Eng., vol. 70, pp. 1539-1548, 2014, doi: 10.1016/j.proeng.2014.02.170.

[11] P. Ghadimi, R. Shademani, and M. Y. Fard, "Performance assessment of the waterjet propulsion system through a combined analytical and numerical approach," Int. J. Phys., vol. 1, no. 2, pp. 22-27, 2013, doi: 10.12691/ijp-1-2-1.

[12] T. Watanabe, T. Kawamura, Y. Takeoshi, M. Maeda, and S. H. Rhee, "Simulation of Steady and Unsteady Cavitation on a Marine Propeller," Proc. 5th Int. Symp. Cavitation (CAV 2003), Osaka, Japan, Novemb. 1-4, no. July, p. GS-12-004 (8 pages), 2003.

[13] T. Magne et al., "Effect of gas content on the cavitating and non-cavitating performance of an axial three-bladed inducer," Multiph. Sci. Technol., vol. 32, no. 2, pp. 81-92, 2020, doi: 10.1615/MultScienTechn.2020031533.

[14] W. M. Rumaherang, "DESIGN SISTEM BLADE POMPA AKSIAL AFP40-500 W.M. Rumaherang * )," no. [1] "DESIGN SISTEM BLADE POMPA AKSIAL AFP40-500 W.M. Rumaherang * ).”.

[15] W. Feng, Q. Cheng, Z. Guo, and Z. Qian, "Simulation of cavitation performance of an axial flow pump with inlet guide vanes," Adv. Mech. Eng., vol. 8, no. 6, pp. 1-8, 2016, doi: 10.1177/1687814016651583.

[16] K. Hosono, Y. Kajie, S. Saito, and K. Miyagawa, "Study on cavitation influence for pump head in an axial flow pump," $J$. Phys. Conf. Ser., vol. 656, no. 1, 2015, doi: 10.1088/1742-6596/656/1/012062.

[17] J. Dang, R. Liu, and C. Pouw, "Waterjet system performance and cavitation test procedures," Third Int. Symp. Mar. Propulsors, no. May, pp. 87-96, 2013.

[18] N. W. Cresswell, G. L. Ingram, and R. G. Dominy, "The impact of diffuser augmentation on a tidal stream turbine," Ocean Eng., vol. 108, pp. 155-163, 2015, doi: 10.1016/j.oceaneng.2015.07.033.

[19] S. Allsop, C. Peyrard, P. R. Thies, E. Boulougouris, and G. P. Harrison, "Hydrodynamic analysis of a ducted, open centre tidal stream turbine using blade element torsitum theory," Ocean Eng., vol. 141, no. January, pp. 531-542, 2017, doi: 10.1016/j.oceaneng.2017.06.040.
[20] Y. Ni, W. Liu, Z. Shen, and X. Pan, "Thrust characteristics and nozzle role of water jet propulsion," Int. J. Fluid Mach. Syst., vol. 10, no. 1, pp. 47-53, 2017, doi: 10.5293/IJFMS.2017.10.1.047.

[21] M. Altosole, G. Benvenuto, M. Figari, and U. Campora, "Dimensionless numerical approaches for the performance prediction of marine waterjet propulsion units," Int. J. Rotating Mach., vol. 2012, no. i, 2012, doi: 10.1155/2012/321306.

[22] H. Ghassemi, S. Majdfar, and H. Forouzan, "Calculations of the Hydrodynamic Characteristics of a Ducted Propeller Operating in Oblique Flow," Cienc. y Tecnol. buques, vol. 10, no. 20, p. 31, 2017, doi: 10.25043/19098642.147.

[23] Rumaherang W. M., Ufie R., Louhenapessy J., Latuny J, "Karakteristik Turbin Propeller Sumbu Horisontal Pembangkit Listrik Tenaga Arus Laut," in Proseding Archipelago Engineering ALE 2018, 2018, no. April, pp. 90-95.

[24] W. M. Rumaherang, "The effect of diameter ratio on energy parameters of the tidal turbine tidal turbine," Din. Tek. Mesin, vol. 10, no. 1 , p. 1, 2020, doi: 10.29303/dtm.v10i1.306.

[25] W. M. Rumaherang, R. Ufie, J. Louhenapessy, and J. Latuny, "Design and Evaluation of Energy Characteristics of a Horizontal Venturi Bulb Turbine Based on Sea Current Data of The," pp. 88-92, 2018.

[26] C. Wang et al., "Numerical simulation on hydraulic characteristics of nozzle in waterjet propulsion system," Processes, vol. 7, no. 12, pp. 1-21, 2019, doi: 10.3390/PR7120915.

[27] J. Yuan et al., "Dynamic analysis of cavitation tip vortex of pump-jet propeller based on DES," Appl. Sci., vol. 10, no. 17, 2020, doi: 10.3390/app10175998. 